\title{
Physicochemical characteristics of groundwater from Kumbakonam Taluk of Thanjavur District - Tamilnadu (India)
}

\author{
D. Kannan ${ }^{1 *}$, S. Nedunchezhian ${ }^{2}$ and N. Mani ${ }^{3}$ \\ ${ }^{1,2,3}$ Department of Chemistry, A. V. V. M. Sri Pushpam College, Poondi, Thanjavur. \\ E-mail: kannanchemist1989@gmail.com
}

Keywords: Physicochemical parameters, Kumbakonam region, ground water quality.

\begin{abstract}
The aim of present study was to assess the quality of ground water from Kumbakonam region in Thanjavur district, and check its fitness for drinking and other purpose. An eight ground water samples were collected from various parts of Kumbakonam region. The physicochemical parameters such as calcium, magnesium, chloride was determined by titration method, sulphate, nitrate, nitrite were analyzed by spectrophotometric method, $\mathrm{pH}$ was determined by $\mathrm{pH}$ metric method and other parameters were analyzed by Indian standard method. Physicochemical parameter of ground water samples were compared with standard limits recommended by BIS. The comparative study of ground water to this region, all the collected water samples are not suitable for drinking purpose, because in this region ground water samples had excess of manganese, calcium, magnesium and iron content.
\end{abstract}

\section{INTRODUCTION}

Water is extremely indispensable for survival of all living organism. The quality of water is vital concern for mankind since it is directly linked with human safety. In India, most of the population is dependent on groundwater as the only source of drinking water supply. Groundwater is believed to be comparatively much clean and free from pollution than surface water [1]. But expanded discharge of industrial effluents, domestic sewage use of fertilizers and pesticides, waste deposit causes the groundwater to become polluted and creates health problems [10].

In developing countries contamination of water supplies by organic chemicals is lesser concern, because most of the health problems are found to be associated with the presence of inorganic chemicals and pathogenic organisms in drinking water. In Thanjavur region some of ground water samples was contaminated, because in the presence of excess of calcium hardness, magnesium hardness, TDS and total alkalinity [8].

The hard water is said to cause serious health problems such as urolithosis, cardiovascular disorder, kidney problems and cancer [7]. Additionally, WHO reports that excess intake of calcium is associate with kidney stones and that of magnesium leads to diarrhea and laxative effect due to change in bowel habit. Water quality of Thiruvarur region most of the areas groundwater is not suitable for drinking purpose, because in the presence of excess hardness [12;3].

In view of the above aspects of groundwater contamination, the present study was undertaken to investigate the possible impact on the groundwater quality of some bore wells of Kumbakonam region in Thanjavur district. Thus, in this paper an attempt has been made to assess the physical and chemical properties of groundwater.

\section{MATERIALS AND METHODS}

\subsection{Study area:}

Kumbakonam is located in Thanjavur district. The studies area lies at $11^{0} 38^{\prime} \mathrm{N}$ and $75^{\circ} 45^{\prime} \mathrm{E}$ latitude. Fig - 1 showed the location of ground water samples was collected from Kumbakonam region and table -1 are given about sampling points of Kumbakonam region. 


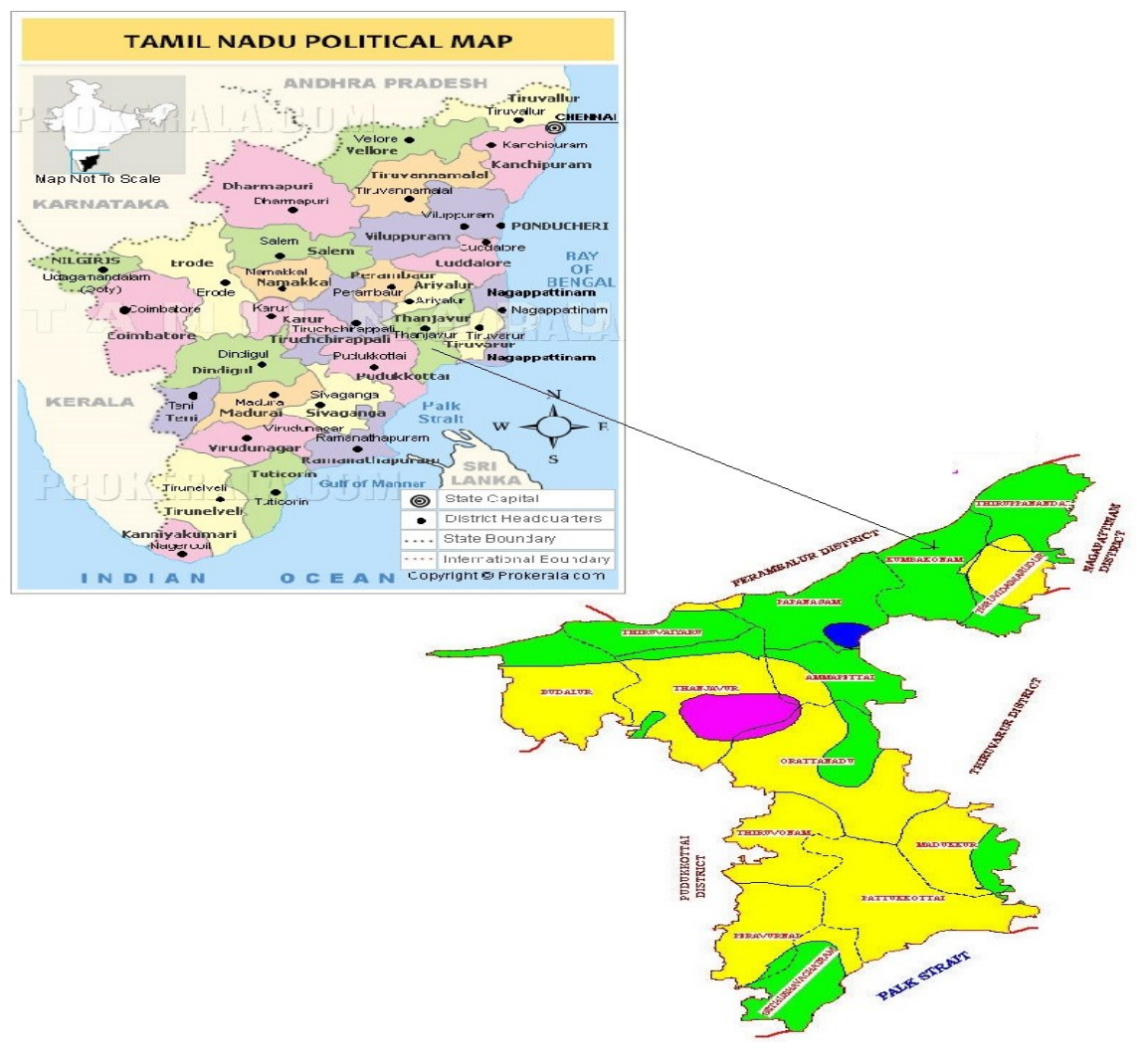

Figure-1: Study Area

Table-1: Sampling points of Kumbakonam region

\begin{tabular}{|c|c|}
\hline Sampling Point & Sampling Point Number \\
\hline Mangudi (East) & S1 \\
\hline Mangudi (West) & S2 \\
\hline Swamimalai (North) & S3 \\
\hline Swamimalai (South ) & S4 \\
\hline Kumbakonam & S5 \\
\hline Baburajapuram & S6 \\
\hline Dharasuram & S7 \\
\hline Ariyapadaiyar & S8 \\
\hline
\end{tabular}

\subsection{Methodology}

Water samples were collected in previously sterilized poly ethylene plastic bottles with cap. The sampling has been carried out in month of MAY - 2015. The samples in the canes (Bottle) were kept in the refrigerator. The physicochemical parameters were determined by IS analytical method. Table-2 is given about methods used for estimation of variation physicochemical parameters.

Table - 2: Methods used for estimation of variation physicochemical parameters.

\begin{tabular}{ccc}
\hline Parameters & Methods & References \\
Od & $\mathrm{pH}-$ Metric method & IS :3025 (Part II) \\
Turbidity & Olfactory method & IS $: 3025$ (Part 5) \\
Electrical Conductivity & Nephelometric method & IS $: 3025$ (Part 10) \\
Total Dissolved Solid & Conduct metric method & IS $3025: 1964$ \\
Total Alkalinity & Gravimetric method & IS : 3025 (Part 16) \\
Chloride & Titrimetric method & IS : 3025 (Part 23) \\
Sulphate & Argento metric method & IS : 3025 (Part 32) \\
& Turbidity method & IS : 3025 (Part 24)
\end{tabular}




$\begin{array}{ccc}\text { Calcium } & \text { EDTA Titrimetric method } & \text { IS : 3025 (Part 40) } \\ \text { Magnesium } & \text { EDTA Titrimetric method } & \text { IS : 3025 (Part 46) } \\ \text { Nitrate } & \text { Chromotropic acid method } & \text { IS :3025 (Part 34) } \\ \text { Nitrite } & \text { Spectrometric method } & \text { IS : 3025 (Part 34) } \\ \text { Phosphate } & \text { Spectrometric method } & \text { IS } 3025: 1964 \\ \text { Fluoride } & \text { Zirconium alizarin method } & \text { IS } 3025: 1964 \\ \text { Manganese } & \text { Colour comparison method } & \text { IS 3025:1964 } \\ \text { Iron } & \text { 1, 10, Phenanthroline method } & \text { IS : 3025 (Part 53) }\end{array}$

\section{RESULTS AND DISCUSSION}

The water samples were collected from various parts of Kumbakonam region, and were analyzed for their physicochemical characteristics. The physicochemical parameters like TDS of water samples was analyzed by gravimetric method, turbidity of the water samples was analyzed by nephelo metric method, alkalinity, calcium, magnesium, chloride was estimated by titrimetric method, and other parameters were analyzed by Indian standard methods. The results were compared with BIS drinking water quality guideline. The estimated physicochemical parameters are reported in the table- 3 and table- 4.

\subsection{Appearance:}

Colour of water may be due to the presence of fine particles in suspension (or) due to certain mineral matter in solution. The entire collected sample had slightly yellow colour, (Table- 3 ).

\subsection{Odour:}

Organic and inorganic chemicals originating from domestic wastes and by decomposition of vegetables matter contributes odour to the water. Entire collected ground water samples had odour less nature, (Table- 3).

\subsection{Turbitity:}

Turbitity in natural water is caused by clay, organic matter, phytoplankton etc., and the turbidity of ground water samples from Kumbakonam region ranged from 10 NTU to 55 NTU, the data are shown in table- 3.

\subsection{Electrical Conductivity:}

Electrical conductivity is the capacity of water to convey current and this may be due to the presence of soluble salts and ionic species which act as conducting medium. Conductivity of the samples ranged between $550 \mu \mathrm{S} / \mathrm{cm}$ to $1790 \mu \mathrm{S} / \mathrm{cm}$. The data are given in table- 3, (Fig- 2).

\subsection{Total Dissolved Solids:}

Many dissolved substance are undesirable in water. Dissolved minerals, gases and organic constituents may produce aesthetically displeasing colour, taste and odour. The total dissolved solids of Kumbakonam region ground water range between $385 \mathrm{mg} / 1$ to $1253 \mathrm{mg} / \mathrm{l}$. The TDS of ground water sample number S1, S3, S5, S6, S7 and S8 is high in Kumbakonam region, (Table - 3), (Fig - 3). If the TDS of drinking water is more than $2000 \mathrm{mg} / \mathrm{l}$, would result to affect gastro intestinal irritation to human beings.

\subsection{Hydrogen ion concentration ( $\mathrm{pH})$ :}

$\mathrm{pH}$ is the measure of capacity (or) alkalinity natural water is alkaline due to the presence of carbonates. The desirable $\mathrm{pH}$ range for drinking water is 6.5 to 8.5 . The water samples had $\mathrm{pH}$ ranged from 6.8 to 7.2. All the samples $\mathrm{pH}$ lying with in BIS permissible limit, showing that all the samples were almost neutral and harmless, (Table- 4), (Fig- 4). 


\subsection{Alkalinity:}

Alkalinity in water is due to the presence of carbonates, bicarbonates and hydroxides. Bicarbonates are the major contributes since they are included from the basic materials in the soil. Alkalinity is also a measure of water to absorb $\mathrm{H}^{+}$ions. Total alkalinity of the samples was found to range from $212 \mathrm{mg} / 1$ to $460 \mathrm{mg} / \mathrm{l}$, (Table- 4), (Fig- 5). The entire collected ground water samples had total alkalinity lying above the BIS desirable limit.

\subsection{Calcium:}

The calcium hardness was recorded in $32 \mathrm{mg} / 1$ to $128 \mathrm{mg} / \mathrm{l}$. Ground water sample number $\mathrm{S} 7$ and S8 were exceeding the BIS limit. Excess calcium hardness of ground water samples causing kidney problem, urolithosis, to human beings. The data are given in table- 4 and fig- 6 .

\subsection{Magnesium:}

The magnesium hardness was recorded in $21 \mathrm{mg} / 1$ to $55 \mathrm{mg} / \mathrm{l}$. The magnesium content of sample numbers S1, S3, S5, S6, S7 and S8 from Kumbakonam region is above the BIS desirable limit, (Table- 4), (Fig- 7).

\section{10. Iron:}

Irons usually exist in ferrous and ferric forms. Generally, the ferric form is predominant in natural water. Excess iron causes stripping of clothes. The samples had iron levels ranged between 0.30 $\mathrm{mg} / \mathrm{l}$ to $1.47 \mathrm{mg} / \mathrm{l}$, (Table- 4), (Fig- 8). The entire ground water samples of Kumbakonam region iron content is above the BIS desirable limit.

\subsection{Manganese;}

Manganese was recorded in $0.33 \mathrm{mg} / 1$ to $3.36 \mathrm{mg} / \mathrm{l}$. All the ground water samples of Kumbakonam region the manganese content level is high compare than BIS desirable limit, (Table- 4), (Fig - 9). Generally the manganese is non - toxic to animals. However, when exceed $100 \mathrm{ppm}$ it cause toxicity to human body and produces fever, muscular fatigue.

\subsection{Nitrite:}

Nitrite in water is due to incomplete oxidation of organic matter containing nitrogen. Nitrites should never be present in drinking water. Nitrite of the samples was found to range from $0.09 \mathrm{mg} / 1$ to $1.65 \mathrm{mg} / \mathrm{l}$. The nitrite content of ground water sample number S1, S3 and S4 had high concentration compare than BIS desirable limit. High concentration of nitrites may cause blue-baby syndrome in children, (Table- 4), (Fig- 10)

\subsection{Nitrate:}

This is the highest oxidized form of Nitrogen. Biological oxidation of nitrogenous substance from sewage is the main source of nitrate. All the samples were found to have nitrate concentration ranging from $1 \mathrm{mg} / \mathrm{l}$ to $8 \mathrm{mg} / \mathrm{l}$. All the water samples had nitrate content lying within the BIS limit, (Table- 4), (Fig- 11).

\subsection{Chlorides:}

Discharge of domestic sewage is the main source of chloride in water. The chloride content estimated in the samples ranged between $44 \mathrm{mg} / 1-284 \mathrm{mg} / \mathrm{l}$, (Table- 4), (Fig- 12). The ground water sample number S1, S7 and S8 have high concentration of chloride ions. An excess of chloride ion react with organic matter in water and produces cancer - causing compounds.

\subsection{Fluoride:}

Industrial waste is the main source of fluoride. The fluoride content was recorded in $0.1 \mathrm{mg} / \mathrm{l}$ to $0.2 \mathrm{mg} / \mathrm{l}$. An entire ground water samples had fluoride content lying well below the detectable limit, (Table- 4), (Fig- 13). 


\subsection{Sulphate:}

Sulphate occurs naturally in all kinds of water. Drainage wastes are the main source of high sulphate concentration. Excess sodium and magnesium sulphate may cause cathartic action. The samples had sulphate levels ranged between $3 \mathrm{mg} / 1$ to $75 \mathrm{mg} / \mathrm{l}$. Entire collected ground water samples lying within BIS limit, (Table- 4), (Fig- 14).

\subsection{Phosphate:}

Generally phosphate occurs in natural water as inorganic (or) organic phosphates. Domestic sewage, agricultural effluents and detergents are the main source of phosphate in water. Excess phosphate may lead to growth of unwanted algae. The sample had phosphate content ranged from $0.03 \mathrm{mg} / 1$ to $0.86 \mathrm{mg} / 1$, (Table- 4), (Fig- 15).

TABLE - 3: Physical parameters of ground water collected from Kumbakonam region.

\begin{tabular}{|c|c|c|c|c|c|c|c|c|c|}
\hline Parameters & S1 & S2 & S3 & S4 & S5 & S6 & S7 & S8 & $\begin{array}{c}\text { BIS } \\
\text { Desirable } \\
\text { limit }\end{array}$ \\
\hline Appearance & $\begin{array}{c}\text { Slightly } \\
\text { Yellow }\end{array}$ & $\begin{array}{c}\text { Slightly } \\
\text { Yellow }\end{array}$ & $\begin{array}{c}\text { Slightly } \\
\text { Yellow }\end{array}$ & $\begin{array}{c}\text { Slightly } \\
\text { Yellow }\end{array}$ & $\begin{array}{c}\text { Slightly } \\
\text { Yellow }\end{array}$ & $\begin{array}{c}\text { Slightly } \\
\text { Yellow }\end{array}$ & $\begin{array}{c}\text { Slightly } \\
\text { Yellow }\end{array}$ & $\begin{array}{c}\text { Slightly } \\
\text { Yellow }\end{array}$ & - \\
\hline Odour & $\begin{array}{c}\text { Odour } \\
\text { less }\end{array}$ & $\begin{array}{c}\text { Odour } \\
\text { less }\end{array}$ & $\begin{array}{c}\text { Odour } \\
\text { less }\end{array}$ & $\begin{array}{c}\text { Odour } \\
\text { less }\end{array}$ & $\begin{array}{c}\text { Odour } \\
\text { less }\end{array}$ & $\begin{array}{c}\text { Odour } \\
\text { less }\end{array}$ & $\begin{array}{c}\text { Odour } \\
\text { less }\end{array}$ & $\begin{array}{c}\text { Odour } \\
\text { less }\end{array}$ & Agreeable \\
\hline Turbidity & 20 & 50 & 35 & 30 & 10 & 45 & 45 & 55 & $\mathbf{2 ~ N T U}$ \\
\hline EC & 1280 & 550 & 725 & 690 & 780 & 735 & 1790 & 1770 & - \\
\hline TDS & 896 & 385 & 508 & 483 & 546 & 515 & 1253 & 1239 & $\mathbf{5 0 0} \mathbf{~ m g / l}$ \\
\hline
\end{tabular}

TDS $=$ Total Dissolved Solids, EC $=$ Electrical Conductance.

TABLE - 4: Chemical parameters of ground water collected from Kumbakonam region.

\begin{tabular}{|c|c|c|c|c|c|c|c|c|c|}
\hline Parameters & S1 & S2 & S3 & S4 & S5 & S6 & S7 & S8 & $\begin{array}{c}\text { BIS } \\
\text { Desirable } \\
\text { limit }\end{array}$ \\
\hline $\mathrm{pH}$ & 6.9 & 6.9 & 7 & 7 & 7.2 & 7.1 & 6.8 & 6.9 & $6.5-8.5$ \\
\hline Alkalinity & 340 & 212 & 320 & 280 & 280 & 236 & 460 & 380 & $200 \mathrm{mg} / 1$ \\
\hline $\mathrm{Ca}^{2+}$ & 61 & 32 & 32 & 43 & 48 & 40 & 128 & 104 & $75 \mathrm{mg} / 1$ \\
\hline $\mathrm{Mg}^{2+}$ & 55 & 23 & 29 & 21 & 38 & 29 & 48 & 40 & $30 \mathrm{mg} / 1$ \\
\hline $\mathrm{Fe}^{3+}$ & 0.30 & 1.47 & 0.64 & 0.59 & 0.30 & 0.75 & 0.96 & 1.25 & $0.3 \mathrm{mg} / 1$ \\
\hline $\mathrm{Mn}^{2+}$ & 2.63 & 0.74 & 0.36 & 0.68 & 0.92 & 0.33 & 3.36 & 1.97 & $0.1 \mathrm{mg} / 1$ \\
\hline $\mathrm{NO}_{2}{ }^{-}$ & 0.09 & $\mathrm{BDL}$ & 0.45 & 1.65 & $\mathrm{BDL}$ & $\mathrm{BDL}$ & $\mathrm{BDL}$ & $\mathrm{BDL}$ & $0.02 \mathrm{mg} / 1$ \\
\hline $\mathrm{NO}_{3}{ }^{-}$ & 7 & 4 & 4 & 2 & 1 & 5 & 7 & 8 & $45 \mathrm{mg} / 1$ \\
\hline $\mathrm{Cl}^{-}$ & 152 & 52 & 44 & 52 & 64 & 72 & 284 & 240 & $200 \mathrm{mg} / 1$ \\
\hline $\mathrm{F}^{-}$ & 0.2 & 0.1 & 0.1 & 0.2 & 0.1 & 0.2 & $\mathrm{BDL}$ & $\mathrm{BDL}$ & $1.0 \mathrm{mg} / \mathrm{l}$ \\
\hline $\mathrm{SO}_{4}{ }^{2-}$ & 72 & 5 & 3 & 4 & 38 & 31 & 39 & 75 & $200 \mathrm{mg} / 1$ \\
\hline $\mathrm{PO}_{4}{ }^{3-}$ & 0.03 & 1.20 & 1.20 & 0.04 & 0.08 & 0.39 & 0.86 & 0.78 & - \\
\hline
\end{tabular}




\section{FIGURES}

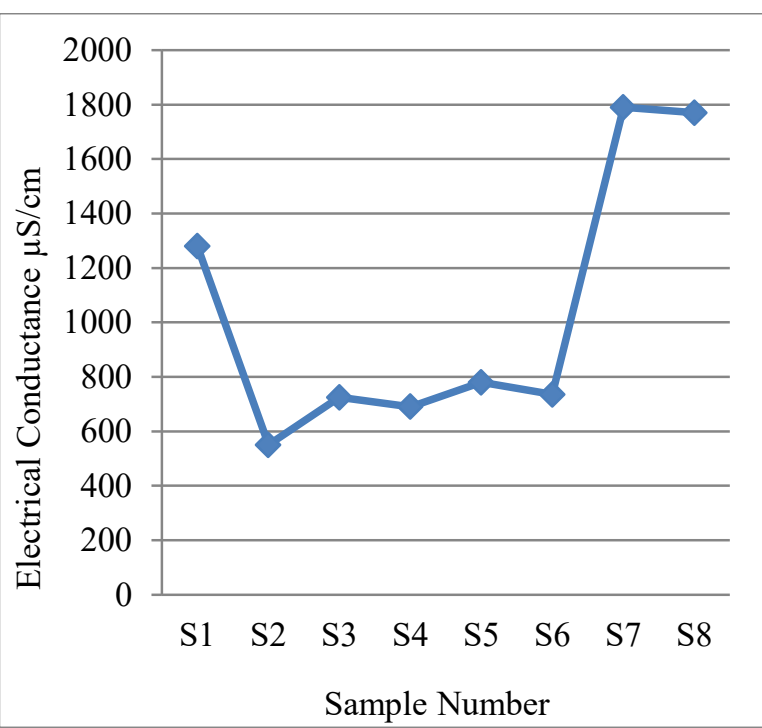

Fig- 2: EC Variation of the Study area.

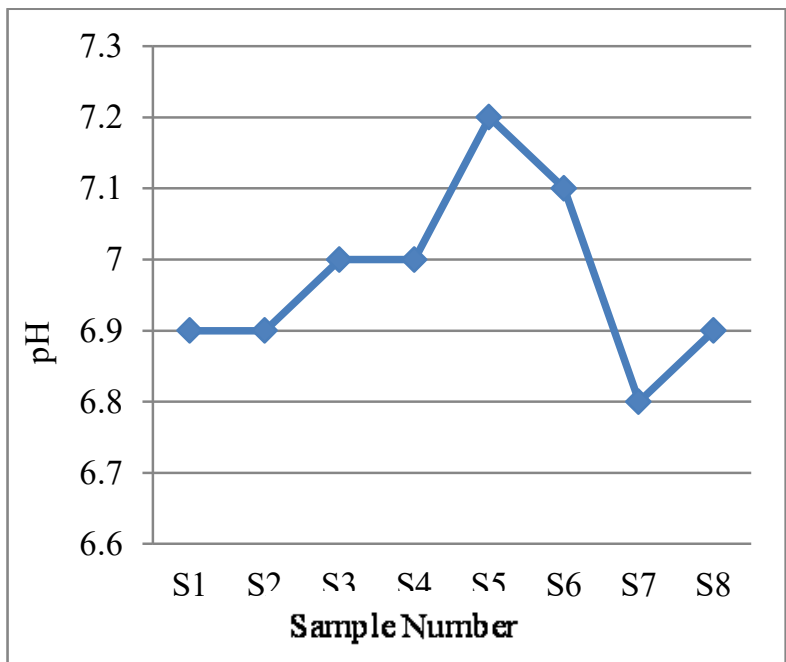

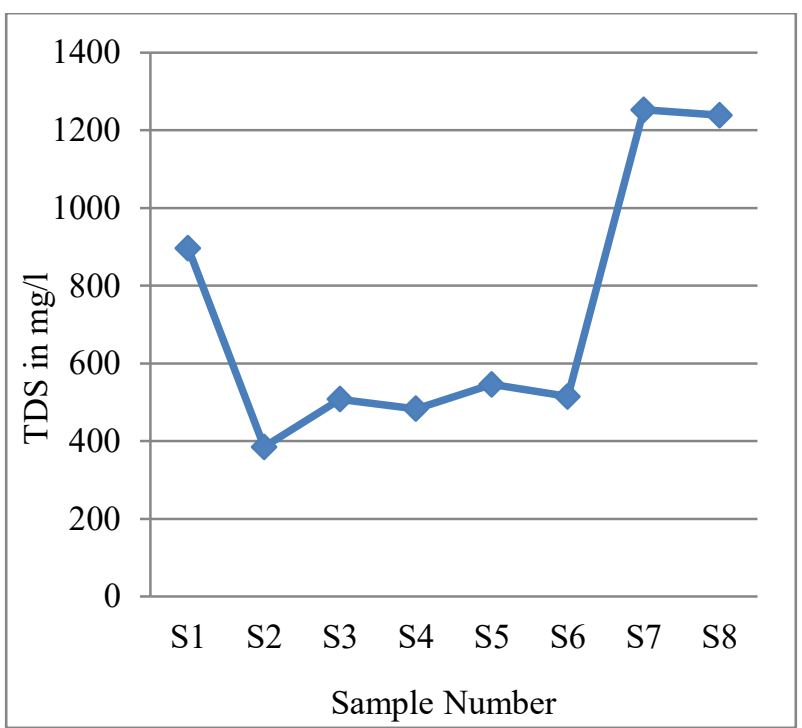

Fig- 3: TDS Variation of the Study area.

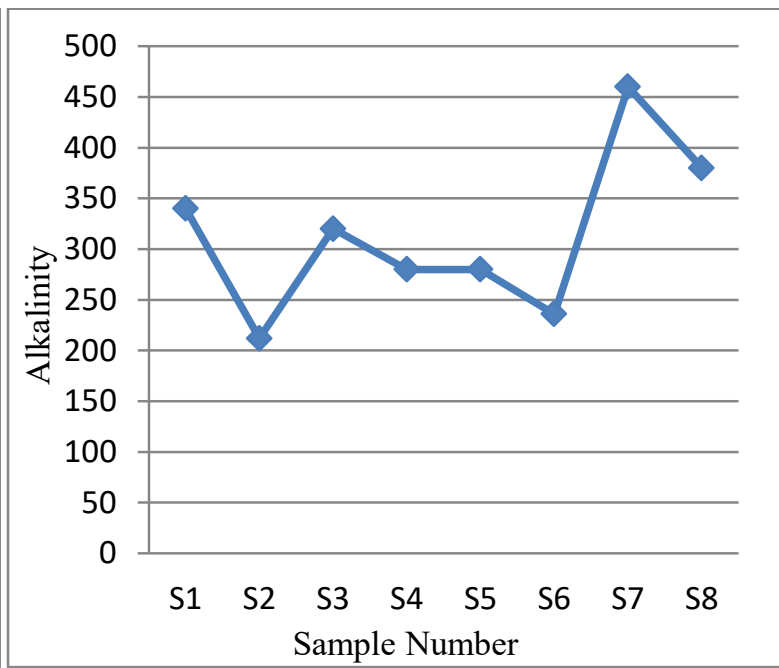

Fig- 4: pH Variation of the Study area. Fig- 5: Total Alkalinity Variation of the Study area.
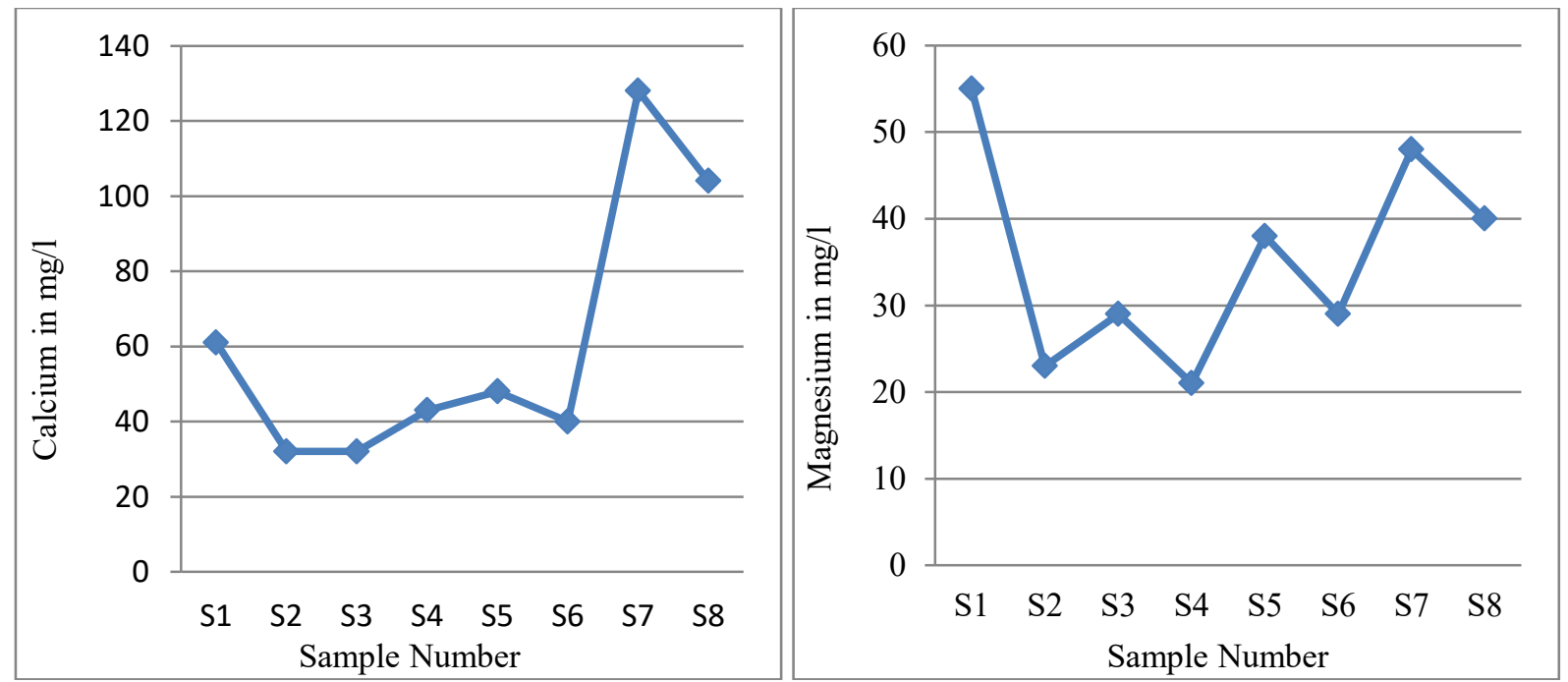

Fig- 6: Calcium Variation of the Study area

Fig- 7: Magnesium Variation of the Study area 


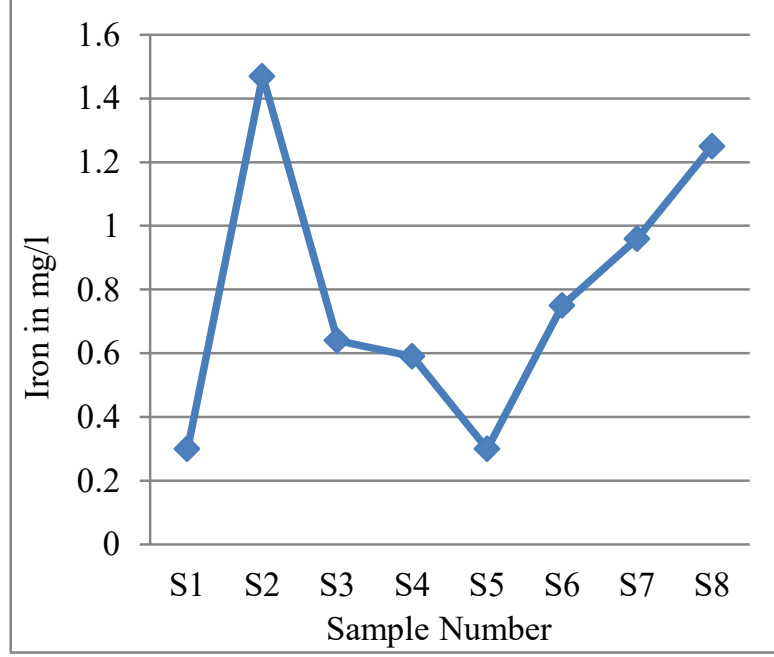

Fig- 8: Iron Variation of the Study area

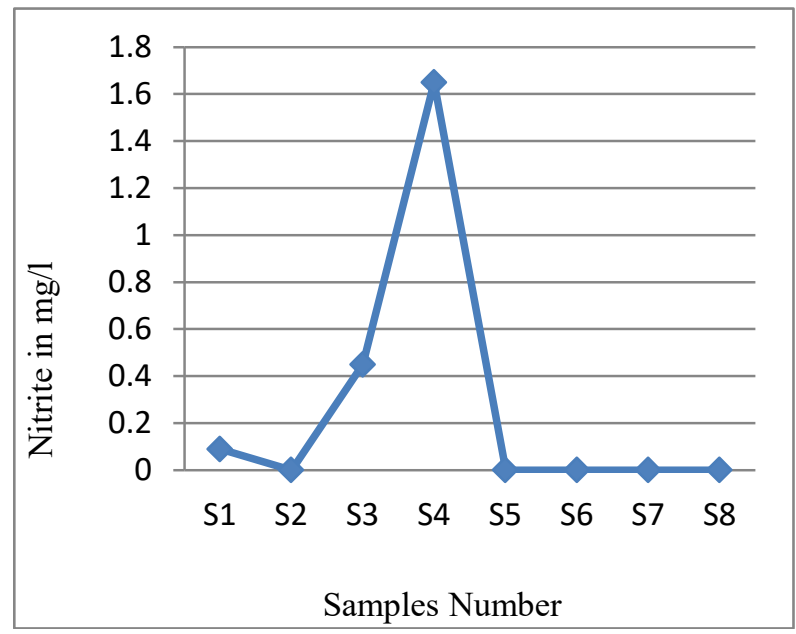

Fig- 10: Nitrite Variation of the Study area

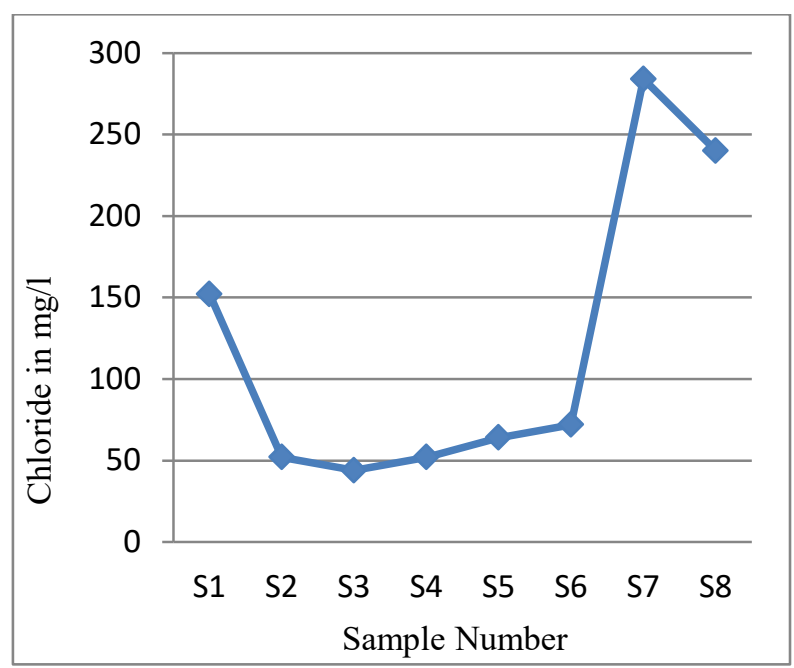

Fig-12: Chloride Variation of the Study area

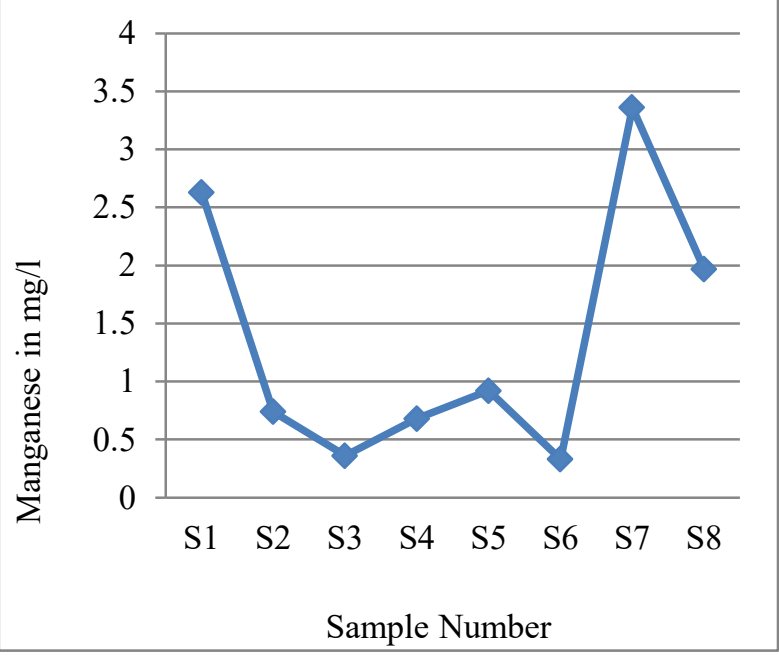

Fig- 9: Manganese Variation of the Study area

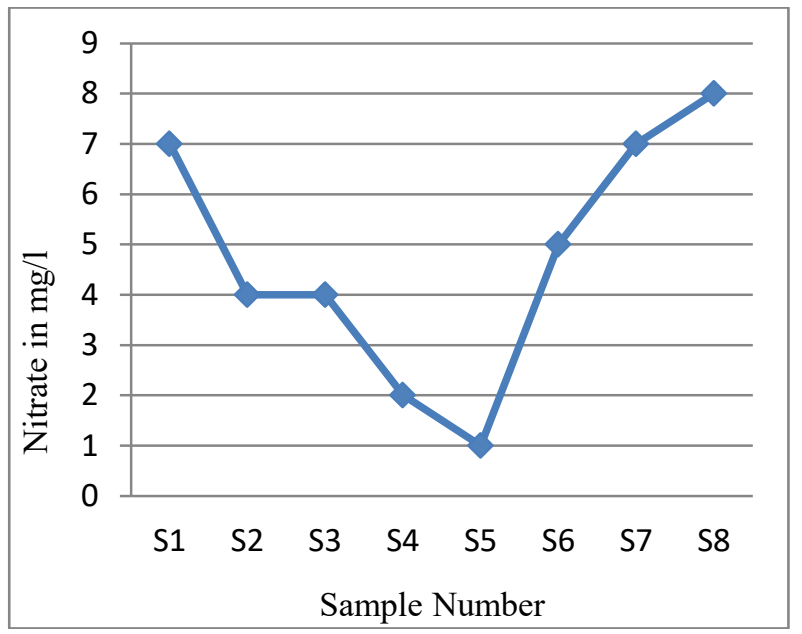

Fig- 11: Nitrate Variation of the Study area

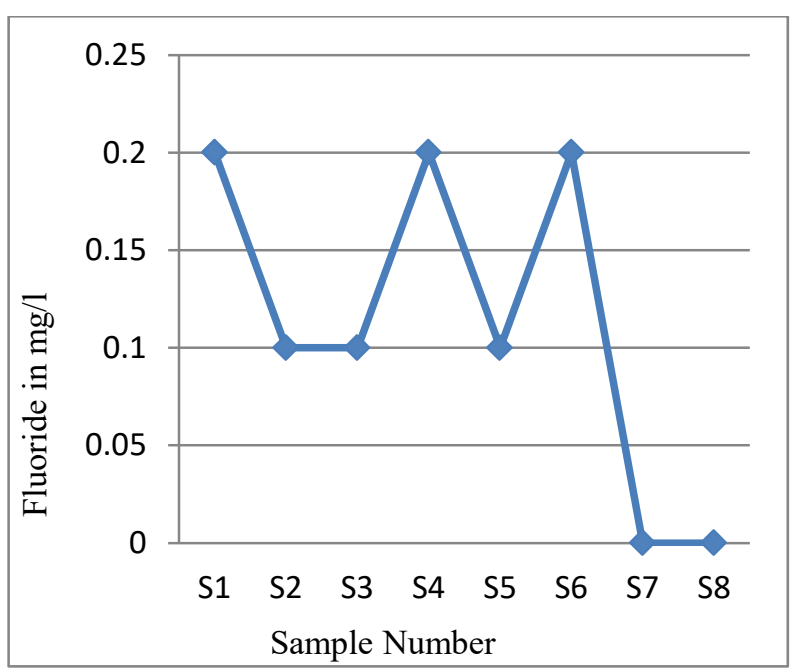

Fig- 13: Fluoride Variation of the Study area 

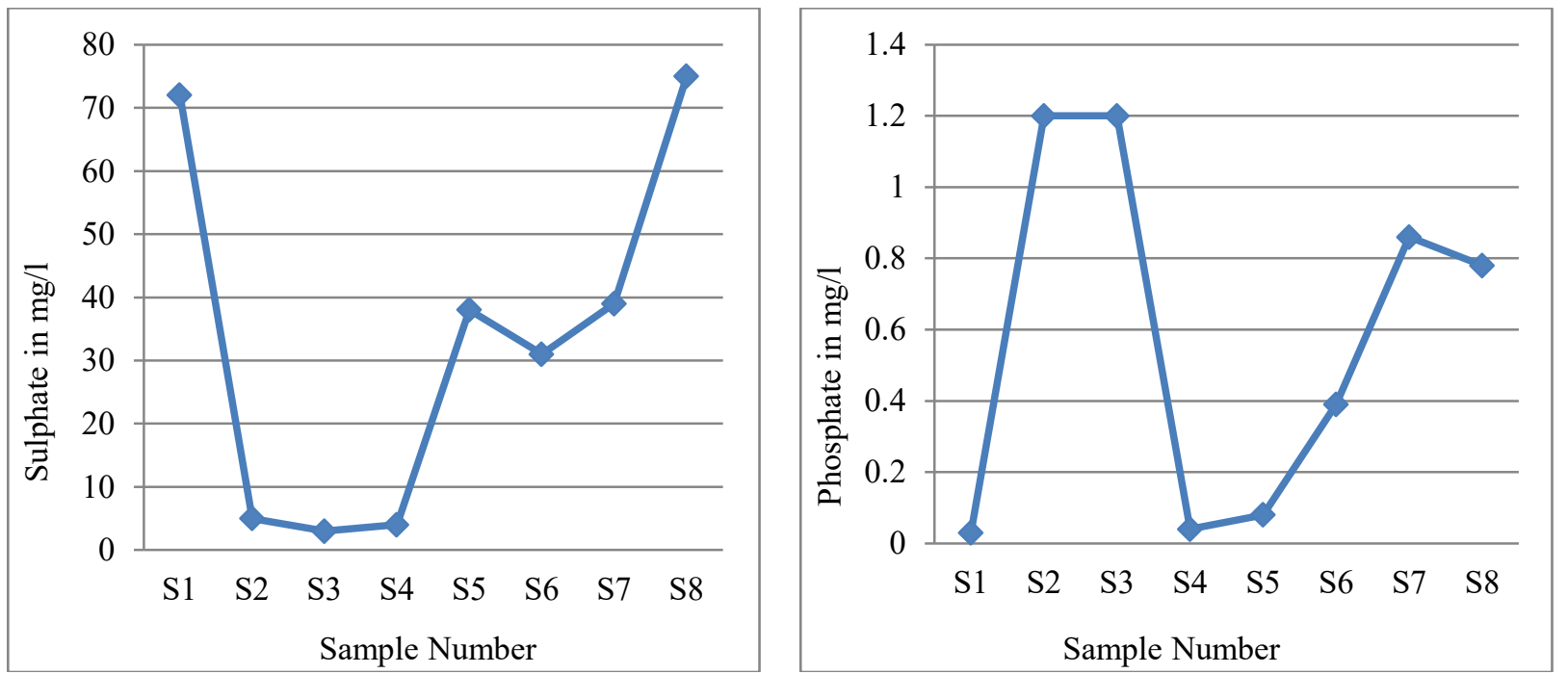

Fig- 14: Sulphate Variation of the Study area

Fig- 15: Phosphate Variation of the Study area

\section{CONCLUSION}

The physicochemical analysis of water samples concluded that the water quality of Kumbakonam region most of the areas groundwater is not suitable for drinking purpose, because in the region ground water had excess of TDS, manganese, chloride and iron. So human being of that region is suffering with various diseases such as gastro intestinal irritations and skin irritation. Rainwater harvesting is one of the solution to minimize the heavy metals concentration in drinking water.

\section{References}

[1] Akinbile, C. O., \& Yusoff, M. S. Environmental impact of leachate pollution on groundwater supplies in

Akure, Nigeria. International Journal of Environmental Science and Development, (2011), 2(1), 8189.

[2] D. Kannan, N. Mani. Mohamad faizal. K, Dharmambal. S. A comparative study of groundwater from Papanasam and Orathanadu region of Thanjavur District, Tamilnadu(India), Int. Journal of Chemistry Environment and Technology. (2013), 1(4), 54-63.

[3] D. Kannan, N. Mani, Thiyagarajan. S. Chemical analysis of ground water from various parts of Thiruvarur and Nagapattinam District Tamilnadu, India. Journal of Der Chemica Sinica, (2014), 5(3), 83-91.

[4] IS: 3025(1964) Method of sampling and test (Physical and Chemical) for water used in industry.

[5] IS: 3025-Methods of sampling and Test (Physical and Chemical) for water and waste water.

[6] Jain P.K. Hydro chemistry and ground water quality of singhari river basin Dist, Chatapur (M.P.). Poll. Res., (1996), 15(4): 407 -409.

[7] Meena, K.S, Gunsaria, R.K. Meena, K, Kumar .N, Meena, P.L, The problem of hardness in ground water of Deoli Tehsil (Tonk District) Rajasthan, Journal of current Chemical and Pharmaceutical Science. (2011), Vol. 2(1): 50- 54.

[8] N. Mani, D. Kannan, Assessment of ground water quality in various parts of Thanjavur district, Tamilnadu (India). Int. Letters of Chemistry, Physics and Astronomy, (2015), 4: 49 - 61. 
[9] O.Akoto, J.Adiyiah, Chemical analysis of drinking water from some communities in the BrongAhafo region. Int. J. Environ. Sci. Tech., (2007), 4 (2):211-214.

[10] Ramakrishnaiah C. R. et al. (2009). Assessment of Water Quality Index for the Groundwater in Tumkur Taluk, Karnataka State, India. E-Journal of Chemistry, 6(2), 523-530. http://dx.doi.org/10.1155/2009/757424.

[11] Saravanakumar. K, and Ranjithkumar. R. Analysis of water quality parameters of groundwater near Ambatture industrial area, Tamilnadu India. Indian Journal of Science Technology, (2011), 4(5), 660-662.

[12] T. Mohana priya, D. Kannan, N. Mani. A comparative study on chemical analysis of ground water from various parts of Thiruvarur district, Tamilnadu(India). Int. Journal of Chemical and Pharmaceutical Analysis, (2014), Vol. 2(1), 58 - 64.

[13] WHO, 2011, Hardness in Drinking - Water Background Document for development of WHO: Guideline for Drinking - Water quality, WHO press. 